\title{
Effect of nitrite treatment on endothelial nitric oxide synthase in human left ventricle biopsy
}

\author{
Jenna Bailey ${ }^{1}$, Sayqa Arif ${ }^{1}$, Jorge Mascaro², Robert S Bonser ${ }^{2}$, Michael P Frenneaux ${ }^{3}$, Melanie Madhani ${ }^{*}$ \\ From 6th International Conference on cGMP: Generators, Effectors and Therapeutic Implications \\ Erfurt, Germany. 28-30 June 2013
}

\begin{abstract}
Background
Acute myocardial infarction remains a major cause of morbidity and mortality worldwide. As such, there is a need for improved cardioprotective strategies. Nitrite represents an alternative source of bioactive nitric oxide (NO) particularly during hypoxia [1], and recent studies have demonstrated that nitrite is protective against myocardial ischemia reperfusion (I/R) injury [2]. Several mechanisms of nitrite bioconversion to $\mathrm{NO}$ have been proposed, such as xanthine oxidase [3], deoxyhaemoglobin and myoglobin [4], but the cytoprotective effects of nitrite therapy remains to be elucidated. Recent experimental data have shown that mice deficient in endothelial nitric oxide synthase (eNOS) exhibit reduced steady state levels of both plasma and cardiac nitrite levels when compared to the wild-type mice. Thus suggesting that nitrite restores NO bioavailability [5]. Herein, we have investigated whether these effects are translated in man and therefore assessed the effects of nitrite therapy on eNOS phosphorylation and expression in human left ventricle (LV) biopsies.
\end{abstract}

\section{Materials and methods}

Patients elected for coronary artery bypass grafting (CABG) surgery were subjected to either placebo (saline) or nitrite treatment $10 \mathrm{mcg} / \mathrm{kg} / \mathrm{min}$ either 30 minutes or 24 hours before surgery. Full thickness LV myocardial free wall tru-cut biopsies were obtained from adjacent non-fibrotic regions just prior to aortic clamping (preischemia) and at 10 minutes post-reperfusion. Biopsies were snap frozen in liquid $\mathrm{N}_{2}$ within 1 minute of collection. To determine the effects of nitrite on eNOS

\footnotetext{
* Correspondence: m.madhani@bham.ac.uk

${ }^{1}$ Centre for Cardiovascular Sciences, College of Medical and Dental Sciences, School of Clinical and Experimental Medicine, University of Birmingham, B15 $2 \pi$, UK

Full list of author information is available at the end of the article
}

expression and phosphorylation status at residue ser1177, Western blot analyses were performed.

\section{Results}

In pre-ischemia LV biopsies, $10 \mathrm{mcg} / \mathrm{kg} / \mathrm{min}$ nitrite administration 24 hours or 30 minutes before CABG surgery caused a significant increase in eNOS phosphorylation at ser1177 when compared to the placebo group. A similar trend was observed for the expression of total eNOS. LV biopsies taken at reperfusion also demonstrated a significant increase in both total eNOS expression and eNOS phosphorylation at ser1177.

\section{Conclusion}

Nitrite upregulates phosphorylation of eNOS at residue s1177 in patients undergoing CABG surgery. Furthermore, total eNOS expression is also increased in these patients, thus suggesting that nitrite may mediate cardioprotection through eNOS signalling pathway and may potentially restore NO bioavailability.

Acknowledgements

This project was funded by the Medical Research Council.

\section{Authors' details}

${ }^{1}$ Centre for Cardiovascular Sciences, College of Medical and Dental Sciences, School of Clinical and Experimental Medicine, University of Birmingham, B15 2TT, UK. ${ }^{2}$ Queen Elizabeth Hospital Birmingham, University of Birmingham, Birmingham, UK. ${ }^{3}$ University of Aberdeen, Aberdeen, UK.

Published: 29 August 2013

\section{References}

1. Lundberg JO, Weitzberg E, Gladwin MT: The nitrate-nitrite-nitric oxide pathway in physiology and therapeutics. Nat Rev Drug Discov 2008, 7:156-167.

2. Baker JE, Su J, Fu X, Hsu A, Gross GJ, Tweddell JS, Hogg N: Nitrite confers protection against myocardial infarction: role of xanthine oxidoreductase, NADPH oxidase and K(ATP) channels. J Mol Cell Cardiol 2007, 43:437-444.

\section{Ciomed Central}

(c) 2013 Bailey et al; licensee BioMed Central Ltd. This is an Open Access article distributed under the terms of the Creative Commons Attribution License (http://creativecommons.org/licenses/by/2.0), which permits unrestricted use, distribution, and reproduction in any medium, provided the original work is properly cited. 
3. Li H, Cui H, Kundu TK, Alzawahra W, Zweier JL: Nitric oxide production from nitrite occurs primarily in tissues not in the blood: critical role of xanthine oxidase and aldehyde oxidase. J Biol Chem 2008, 283:17855-17863.

4. Shiva S, Huang Z, Grubina R, Sun J, Ringwood LA, MacArthur PH, Xu X, Murphy E, Darley-Usmar VM, Gladwin MT: Deoxymyoglobin is a nitrite reductase that generates nitric oxide and regulates mitochondrial respiration. Cir Res 2007, 100:654-661.

5. Bryan NS, Clavert HW, Gundewar S, Lefer DJ: Dietary nitrite restores NO homeostasis and is cardioprotective in eNOS deficient mice. Free Radical Biol Med 2008, 45:468-474.

doi:10.1186/2050-6511-14-S1-P3

Cite this article as: Bailey et al:: Effect of nitrite treatment on endothelial nitric oxide synthase in human left ventricle biopsy. BMC Pharmacology and Toxicology 2013 14(Suppl 1):P3.

\section{Submit your next manuscript to BioMed Central} and take full advantage of:

- Convenient online submission

- Thorough peer review

- No space constraints or color figure charges

- Immediate publication on acceptance

- Inclusion in PubMed, CAS, Scopus and Google Scholar

- Research which is freely available for redistribution

Submit your manuscript at www.biomedcentral.com/submit 